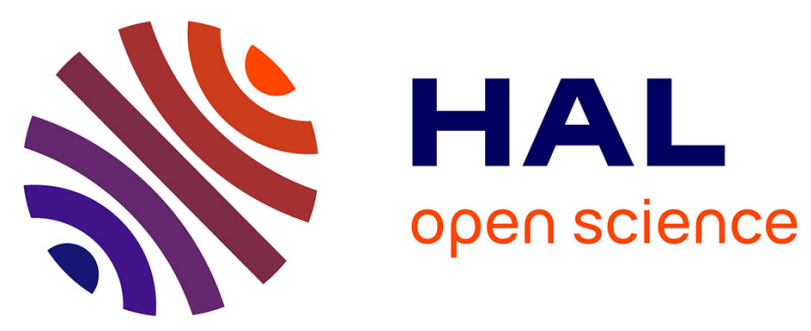

\title{
Use of skin and blubber tissues of small cetaceans to assess the trace element content of internal organs
}

Aurore Aubail, Paula Méndez-Fernandez, Paco Bustamante, Carine Churlaud, M. Ferreira, José Vingada, Florence Caurant

\section{- To cite this version:}

Aurore Aubail, Paula Méndez-Fernandez, Paco Bustamante, Carine Churlaud, M. Ferreira, et al.. Use of skin and blubber tissues of small cetaceans to assess the trace element content of internal organs. Marine Pollution Bulletin, 2013, 76 (1-2), pp.158-169. 10.1016/j.marpolbul.2013.09.008 . hal-00873396

\section{HAL Id: hal-00873396 https://hal.science/hal-00873396}

Submitted on 15 Oct 2013

HAL is a multi-disciplinary open access archive for the deposit and dissemination of scientific research documents, whether they are published or not. The documents may come from teaching and research institutions in France or abroad, or from public or private research centers.
L'archive ouverte pluridisciplinaire HAL, est destinée au dépôt et à la diffusion de documents scientifiques de niveau recherche, publiés ou non, émanant des établissements d'enseignement et de recherche français ou étrangers, des laboratoires publics ou privés. 
Use of skin and blubber tissues of small cetaceans to assess the trace element content of internal organs

A. Aubail ${ }^{a, \dagger}$, P. Méndez-Fernandez ${ }^{\text {a, b, }{ }^{*},}$, P. Bustamante ${ }^{a}$, C. Churlaud ${ }^{\text {a }}$, M. Ferreira ${ }^{\text {c }}$, J.V. Vingada $^{\text {c, d }}$, F. Caurant ${ }^{\text {a }}$

${ }^{\text {a } L i t t o r a l ~ E n v i r o n n e m e n t ~ e t ~ S o c i e ́ t e ́ s ~(L I E N S S), ~ U M R ~} 7266$ CNRS-Université de La Rochelle, 2 rue Olympe de Gouges, 17042 La Rochelle Cedex 01, France

b Coordinadora para o Estudo dos Mamiferos Mariños (CEMMA), Apdo. 15, Pontevedra, 36380, Spain

c Centro de Biologia Molecular e Ambiental (CBMA)/Sociedade Portuguesa de Vida Selvagem (SPVS), Dep. de Biologia, Universidade do Minho, Campus de Gualtar, Braga, 4710-057, Portugal

${ }^{\mathrm{d}}$ Centre for Environmental and Marine Studies (CESAM), Universidade de Aveiro, Campus Universitário de Santiago, 3810-193 Aveiro, Portugal

\section{$\uparrow$ These authors contributed equally to this work}

* Corresponding author: Tel: +33 0613618439

E-mail address: paula.mendez_fernandez@univ-lr.fr (P. Méndez-Fernandez) 


\begin{abstract}
In order to evaluate the use of biopsy samples as non-destructive tool for assessing trace element concentrations in small cetaceans, the concentrations of 14 trace elements were determined in skin, blubber, liver and kidneys of four species of small cetaceans (i.e. common dolphin Delphinus delphis, harbour porpoise Phocoena phocoena, bottlenose dolphin Tursiops truncatus and striped dolphin Stenella coeruleolba), stranded and/or by-caught along the NE Atlantic Ocean coast between 2001 and 2008. Only Cu, Fe, Hg, Mn, Ni and Zn were above the detection limit of the instruments and showed recoveries satisfactory enough to be interpreted. Among these trace elements, $\mathrm{Hg}$ was the only one showing a significant correlation between concentrations in and those in liver and kidneys. In consequence, skin and blubber can only be used as non-invasive monitoring tissues to investigate $\mathrm{Hg}$ bioaccumulation in internal tissues for cetacean populations.
\end{abstract}

Keywords: Trace element; Bioaccumulation; Skin; Blubber; Biopsy; Cetaceans 


\section{Introduction}

Many studies have investigated trace element concentrations in marine mammal tissues, and especially in cetaceans (i.e. Law, 1996; O'Shea, 1999; Das et al., 2003 for review). Indeed, due to their long lifespan and their position at the top of the marine food webs, cetaceans are considered to be good indicators for the monitoring of elemental contamination in the marine environment (Wagemann and Muir, 1984; Wagemann et al., 1996; Monaci et al., 1998; Bellante et al., 2011). Exposure to trace elements is commonly monitored through the determination of their concentrations in the tissues involved in their storage and detoxification. However, these studies are generally based on by-caught or more generally on naturally stranded animals (i.e. unknown cause of death), and, as target organs, kidneys and liver are the tissues the most commonly analysed. However, the number of biopsies sampling on board of various expeditions increases allowing a growing access to skin and blubber samples (Noren and Mocklin, 2012) for the study of the genetic structure of cetacean populations and/or their trophic ecology through stable isotope analysis for example (e.g. Hooker et al., 2001; Herman et al., 2005; Kizska et al., 2010; Witteveen et al., 2011). Consequently, biopsies can also be used to investigate the exposure and bioaccumulation of contaminants in cetaceans' overtime and in healthy animals, even when carcasses are not available (e. g. around tropical islands or in oceanic open waters). Previously, skin biopsies have been suggested as a non-destructive tissue for assessing exposure to organic contaminants and the ecotoxicological risk associated for marine mammals (Fossi and Marsili, 1997; Fossi et al., 2004). Some studies have also investigated the potential use of skin samples obtained from free-ranging cetaceans to monitor the bioaccumulation of trace elements in internal organs of striped dolphins Stenella coeruleolba (Monaci et al., 1998), minke whales Balaenoptera acutorostrata (Kunito et al., 2002), Dall's porpoises Phocoenoides dalli (Yang et al., 2002) or more recently, bottlenose dolphins Tursiops truncatus (Stavros et al., 2011). Contrarily to skin, blubber has not been so much investigated for its potential use in trace element monitoring and only a limited number of studies reported trace element concentrations in this tissue (Fujise et al., 1988; Marcovecchio et al., 1990; Carvalho et al., 2002; Bustamante et al., 2003; Roditi-Elasar et al., 2003). Blubber constitutes nevertheless an important part of the material obtained from a common biopsy (Krützen et al., 2002), and it appears therefore interesting to consider both tissues. 
Even if kidneys and liver remain the target organs and references in terms of threshold levels of concentrations and dose-effects studies, there is a need to establish relationships between elemental levels found in skin and blubber and those primarily measured in those internal tissues. Thus, it would appear therefore relevant to use biological samples obtained from healthy free-ranging animals for assessing bioaccumulation of contaminants and the potential toxicological effects associated. Besides the non-invasive or destructive aspect of this method of investigation, more generally, the monitoring of trace element levels in living cetaceans could inform on the environmental contamination.

Thus, the purpose of this study was to measure the concentrations of trace elements in the blubber and skin of four species of small cetaceans, considering the influence of biological factors, such as age and sex, on those levels. Then, relationships between these concentrations and those previously determined in the internal organs were investigated to assess the potential of skin and blubber tissues as non-invasive monitoring tissues of kidneys and liver trace elements burden of free-ranging cetacean species.

\section{Materials and methods}

\subsection{Origin and preparation of samples}

Samples were obtained from 131 cetaceans stranded and/or by-caught along the NE Atlantic Ocean coast between 2001 and 2008 (Fig. 1 and Table 1). Four species were represented, common dolphin Delphinus delphis $(\mathrm{n}=79)$, harbour porpoise Phocoena phocoena $(\mathrm{n}=17)$, striped dolphin Stenella coeruleoalba $(\mathrm{n}=19)$ and bottlenose dolphin Tursiops truncatus $(\mathrm{n}=$ 16). The biological tissues were collected and the length, weight and sex of each animal were recorded, whenever possible, by the French (Observatoire PELAGIS-Centre de Recherche sur les Mammifères Marins), Galician (Coordinadora para o Estudo dos Mamiferos Mariños, CEMMA), and Portuguese (Sociedade Portuguesa de Vida Selvagem, SPVS) stranded networks, following a standard necropsy protocol defined by the European Cetacean Society (after Kuiken and Garcia Hartmann, 1991). After the necropsies, all the tissue samples were stored at $-20^{\circ} \mathrm{C}$ until being processed in the laboratory. Since decomposition state can affect results from trace element analysis, individuals selected for analysis were those with condition code 1 to 3 , i.e. originally stranded alive, freshly dead or moderately decomposed (Kuiken and Garcia Hartmann, 1991). Among the sampled tissues, kidneys and liver were analysed for trace elements previously for the purpose of other studies and the corresponding data already 
partly published (see Lahaye et al., 2005, 2006, 2007a, 2007b; Méndez-Fernandez et al., in press).

Prior to analysis, all samples were freeze-dried for $48 \mathrm{~h}$. Skin samples were subsequently ground while blubber samples were sliced into small pieces. Later on, the age of the individuals was estimated by counting annual layers or Growth Layer Groups in thin dental sections after decalcification of the teeth and following adapted methods based on Lockyer (1993), Hohn and Lockyer (1995), Rogan et al. (2004) and Perrin and Myrick (1980). Age determination was assumed by the Observatoire PELAGIS and the Instituto de Investigaciones Marinas (C.S.I.C) of Vigo in Spain. Number of individuals analysed per species, sex ratio and age within the four studied species (mean \pm SD) are reported in Table 1 . In addition, 30 individuals were selected for a prior-test in order to investigate the elemental concentrations distribution within fat tissue. Blubber samples of the selected individuals were thus cut in three equal layers, i.e. the inner (close to muscle), the outer (close to skin) and the intermediary one, and concentrations of trace elements were measured in each of them for all 30 individuals.

\subsection{Analytical procedures for $\mathrm{Hg}$ analysis}

Total $\mathrm{Hg}$ concentrations measurements were performed using a solid sample atomic absorption spectrometer AMA-254 (Advanced Mercury Analyser-254 from Altec ${ }^{\circledR}$ ). The use of this instrument does not require chemical pre-treatments. For both tissues, subsamples were analysed in duplicate and from 10 to $30 \mathrm{mg}$ of dried material were directly introduced in the AMA-254 for subsequent analysis. The analytical process consists in a drying period at $105^{\circ} \mathrm{C}$, prior to a combustion phase at $750^{\circ} \mathrm{C}$ which leads to the release of $\mathrm{Hg}$ from the samples. Subsequently, the $\mathrm{Hg}$ vapour produced is carried by an oxygen flow to a gold amalgamator, and trapped on its surface. Thereafter, the collected $\mathrm{Hg}$ is released from the amalgamator by a short heat-up to $800^{\circ} \mathrm{C}$, and carried in a pulse through a spectrophotometer, where it is detected by atomic absorption. The operating times used for our samples were $10 \mathrm{~s}$ for the drying time, 150 s for the decomposition time, and $45 \mathrm{~s}$ for the waiting time.

The analytical quality of the $\mathrm{Hg}$ measurements by the AMA-254 was controlled by including a blank and the certified reference material TORT-2 (Lobster hepatopancreas) from the National Research Council of Canada (NRCC), at the beginning and at the end of the analytical cycle, and by running them every 15 analyses. Results of the TORT-2 measurements showed a good precision with a relative standard deviation of $3.68 \%$, and an 
accuracy of $89 \%$ of the assigned concentration. All data are presented on a dry weight basis $\left(\mu \mathrm{g} \cdot \mathrm{g}^{-1} \mathrm{dw}\right)$ and the detection limit was $0.00001 \mu \mathrm{g}$.

\subsection{Analytical procedures for the analysis of the other trace elements}

Concentrations of $\mathrm{Ag}, \mathrm{As}, \mathrm{Cd}, \mathrm{Co}, \mathrm{Cr}, \mathrm{Cu}, \mathrm{Fe}, \mathrm{Mn}, \mathrm{Ni}, \mathrm{Pb}, \mathrm{Se}, \mathrm{V}$ and $\mathrm{Zn}$ analyses were performed with a Varian Vista-Pro ICP-AES (for Inductively Coupled Plasma Atomic Emission Spectrophotometry) and a Thermofisher Scientific XSeries 2 ICP-MS (for Inductively Coupled Plasma Mass Spectrometry). For ICP-AES and ICP-MS measurements and both tissues, aliquots of samples from 0.1 to $0.3 \mathrm{~g}$ were digested with $6 \mathrm{~mL}$ 67-70\% $\mathrm{HNO}_{3}$ and $2 \mathrm{~mL} \mathrm{34-37 \%} \mathrm{HCl}$ (both from Merck and suprapur quality). Acid digestion of the samples was carried out overnight at room temperature and then in a Milestone microwave oven (30 min with constantly increasing temperature up to $120^{\circ} \mathrm{C}$, then $15 \mathrm{~min}$ at this maximal temperature). Each sample was made up to $50 \mathrm{~mL}$ with milli-Q water. For samples with a weight $<0.1 \mathrm{~g}$, the mixture used was $3 \mathrm{ml} 67-70 \% \mathrm{HNO}_{3} / 1 \mathrm{~mL} 34-37 \% \mathrm{HCl}$ and milliQ water was made up to $25 \mathrm{~mL}$. Two certified reference materials (CRMs) and one blank treated and analyzed in the same way as the samples, were included in each analytical batch. CRMs were DOLT-4 (dogfish liver) and TORT-2 (lobster hepatopancreas) both from the NRCC. For $\mathrm{Ag}, \mathrm{Cd}, \mathrm{Co}, \mathrm{Cu}, \mathrm{Fe}, \mathrm{Mn}, \mathrm{Ni}$ and $\mathrm{Zn}$, the measurements were in satisfactory agreement with the given certified values and showed mean recoveries of $90 \%$ for TORT-2 and $91 \%$ for DOLT-4. The ICP-MS quantification limits $\left(\mu \mathrm{g} . \mathrm{L}^{-1}\right)$ were $0.1 \mathrm{for} \mathrm{Ag}, \mathrm{Cd}$ and Co, 0.2 for $\mathrm{Ni}, 0.5$ for $\mathrm{Mn}$ and $\mathrm{Cu}, 5$ for $\mathrm{Fe}$ and $\mathrm{Zn}$. All elemental concentrations are expressed in $\mu \mathrm{g} \cdot \mathrm{g}^{-1} \mathrm{dw}$.

Finally, all the samples were analysed in duplicate and trace elements protocol was validated by an international intercalibration exercise (Christopher et al., 2007)

\subsection{Data treatment}

Shapiro-Wilk of normality and Bartlett test of homogeneity of variances were used to test the assumptions of parametric tests on the data. Consequently, when trace element concentrations were not normally distributed, transformed data (i.e. log-transformed) were used for further analyses.

In order to test the influence of age and sex on the elemental concentrations of the four species the analysis of variance (ANOVA) was used. When age has an influence on the 
elemental concentrations, the linear regression analysis were then performed to test elemental bioaccumulation with age and by tissue. ANOVA was also used to compare trace element concentrations among tissues and to investigate the elemental distribution in the different blubber layers. In case of significant differences, Tukey multi-comparison tests were subsequently applied to compare the multiple means. Finally, Pearson correlation coefficient test was applied when investigating the relationships between log-transformed concentrations of trace elements in the various tissues.

The levels of significance for statistical analyses were always set at $\alpha=0.05$ and performed using the free software R, version 2.15.1 (R Development Core Team, 2010).

\section{Results}

\subsection{Trace element concentrations}

Among the considered elements, $\mathrm{Cu}, \mathrm{Fe}, \mathrm{Hg}, \mathrm{Mn}, \mathrm{Ni}$ and $\mathrm{Zn}$ showed concentrations above the detection limits (DL) of the analytical instruments, while $\mathrm{Ag}, \mathrm{Cd}$ and Co concentrations were below the DL in both blubber and skin tissues. Furthermore, $\mathrm{Cu}$ was frequently below the DL in the blubber, and $\mathrm{Mn}$ and $\mathrm{Ni}$ were not systematically detected either in all skin or in all blubber samples.

Trace element concentrations measured in skin and blubber for the four cetacean species are presented in Table 2; similarly, the concentrations in liver and kidney, which have been determined previously for other studies, are summarised in Table 3. Across all individuals, the ranking of highest to lowest mean elemental concentration detected in skin was $\mathrm{Zn}>\mathrm{Fe}>\mathrm{Cu}$ $>\mathrm{Hg}>\mathrm{Mn}>\mathrm{Ni}$, while it was $\mathrm{Zn}>\mathrm{Fe}>\mathrm{Ni}<\mathrm{Cu}>\mathrm{Mn}>\mathrm{Hg}$ in blubber, with significantly lower levels found in blubber compared to those in skin for $\mathrm{Ni}(p<0.05)$, and for $\mathrm{Cu}, \mathrm{Hg}$ and $\mathrm{Zn}(p<0.001)$. Furthermore, significant differences in concentrations were found among the four tissues for each element (ANOVA, $p<0.001$ for the six elements; Fig. 2). More specifically, the highest to lowest mean $\mathrm{Cu}$ and $\mathrm{Hg}$ concentration were found in liver > kidneys $>$ skin $>$ blubber $(p<0.001)$, and Zn in skin $>$ liver $>$ kidneys $=$ blubber $(p<0.001)$. Concerning $\mathrm{Ni}$, the liver exhibited significantly lower concentrations compared to the other tissues ( $p<0.05$ with skin and $p<0.001$ with kidneys and blubber), and the blubber showed significantly higher Ni concentrations than skin $(p<0.05)$. 


\subsection{Trace element distribution in blubber}

Across all individuals, no significant difference among the three layers of blubber was detected for $\mathrm{Cu}, \mathrm{Fe}, \mathrm{Hg}, \mathrm{Mn}$ and $\mathrm{Ni}$ concentrations, while significant differences were found for $\mathrm{Zn}$ ones (ANOVA, $\mathrm{F}=42.98, p<0.001$ ). Thus, concentrations of $\mathrm{Zn}$ increased from the inside toward the outside of blubber (Fig. 3).

\subsection{Effect of sex and age on trace element concentrations}

Gender did not influence the concentrations of the different analysed elements neither in skin nor in blubber, for each of the species or across all of them (ANOVA, $p>0.05$ ). Therefore, data obtained for males and females were pooled for further analyses.

No significant difference in age was found among species (ANOVA, $\mathrm{F}=0.75, p=0.53$ ). $\mathrm{Hg}$ concentrations in both skin and blubber increased significantly with age for each species (linear regression, $p<0.001$ for common dolphins and striped dolphins; $p<0.01$ for harbour porpoises and bottlenose dolphins) (Fig. 4). Regarding the other elements, no significant relation was observed with age, except for Mn concentrations in the blubber of common dolphins (linear regression, $p<0.05$ ).

\subsection{Relationships between trace element concentrations}

Significant correlations between log-transformed element concentrations in the various tissues for each species and across all individuals are presented in the Table 4. Mercury stands out by its strong tissue-to-tissue correlations in all species and across all individuals (Pearson's correlation, $0.63<r<0.94$, Fig. 5). The following equations and coefficients of correlation associated were found:

$$
\begin{array}{ll}
\log (\text { Hg skin })=0.331 * \log (\text { Hg liver })-0.161 & r^{2}=0.563 \\
\log (\text { Hg skin })=0.589 * \log (\text { Hg kidney })-0.243 & r^{2}=0.644 \\
\log (\text { Hg blubber })=0.656 * \log (\text { Hg liver })-1.553 & r^{2}=0.652 \\
\log (\text { Hg blubber })=0.996 * \log (\text { Hg kidney })-1.568 & r^{2}=0.544
\end{array}
$$

Concerning the other trace elements, only $\mathrm{Cu}$ and $\mathrm{Zn}$ in common dolphins and across all individuals showed correlations between blubber and internal tissues (see Table 4). It has to be noticed that all correlations between skin and internal organs that appeared across all individuals for $\mathrm{Ni}, \mathrm{Mn}, \mathrm{Fe}$ and $\mathrm{Zn}$ are negative. 


\section{Discussion}

\subsection{Bioaccumulation and tissue distribution of trace elements in cetaceans}

Trace elements enter the marine environment deriving from both natural and anthropogenic sources. They generally occur at low concentrations in oceans (Bryan, 1984), but cetaceans accumulate great amounts mainly through diet, with bioaccumulation varying on a species-, element-, and tissue-specific basis (Aguilar et al., 1999; Bowles, 1999; Das et al., 2003). Feeding habits are the main factor of variation of body burden elemental concentrations, and differences in diet result consequently in variations in elemental concentration levels (e.g., Kunito et al., 2002; Lahaye et al., 2005, 2007b; Hong et al., 2012; Méndez-Fernandez et al., in press). Trace elements are commonly divided in essential and non-essential elements. Most of the studies usually focus on non-essential elements, i.e. $\mathrm{Ag}, \mathrm{Cd}, \mathrm{Hg}$ and $\mathrm{Pb}$, because of their potential toxicity for the organisms even at low concentrations (Das et al., 2003). Nevertheless, many of the trace elements which are essential for health, like $\mathrm{Cu}, \mathrm{Fe}, \mathrm{Mn}$ or $\mathrm{Zn}$ are theoretically subjected to regulation mechanisms contrarily to the non-essential ones (Law, 1996; Bowles, 1999). As a result, a narrow range of variation of element concentrations, as observed in our study for $\mathrm{Cu}, \mathrm{Mn}$ and $\mathrm{Zn}$ (except for $\mathrm{Zn}$ in skin) across all tissues and species, is characteristic of essential elements (Thompson, 1990; Law et al., 1991, 1992), and witnesses of their good regulation in these four cetacean species. For $\mathrm{Cu}$ and $\mathrm{Zn}$, this homeostatic control may be operated by proteins such as the well-known metallothioneins (Muir et al., 1988).

Concerning the inter-tissue variations, trace element levels measured in the internal organs kidney and liver were significantly higher than those in skin and blubber tissues, except for $\mathrm{Ni}$ and Zn. Furthermore, skin showed significantly higher levels of trace elements than blubber, which is in agreement with what has been previously reported for $\mathrm{Cu}, \mathrm{Fe}, \mathrm{Hg}, \mathrm{Mn}$ and $\mathrm{Zn}$ in previous studies (e.g. Fujise et al., 1988; Marcovecchio et al., 1990; Carvalho et al., 2002; Roditi-Elasar et al., 2003; Wagemann and Kozlowska, 2005). Of all elements above the detection limit, Fe followed by $\mathrm{Zn}$ exhibited the highest concentrations in kidney and liver, while the opposite pattern was found for skin and blubber. High $\mathrm{Zn}$ concentrations in skin compared to the other tissues have also been reported for other marine mammals (i.e. beluga whale (Delphinapterus leucas) and narwhal (Monodon monoceros) (Wagemann et al., 1996), bottlenose and striped dolphin (Honda et al., 1982; Monaci et al., 1998; Roditi-Elasar et al., 
2003; Stavros et al., 2007), common dolphin (Carvalho et al., 2002), Dall's porpoise (Fujise et al., 1988; Yang et al., 2002), minke whale (Kunito et al., 2002), and also in pinnipeds (Yamamoto et al., 1987; Watanabe et al., 1996). This can be explained by the essential physiological functions that $\mathrm{Zn}$ plays in skin tissue, such as in wound recovery (Yang et al., 2002), and specifically to cetaceans, in protection against photo-oxidative damages induced by solar ultraviolet rays as described for human skin fibroblasts by Emonet-Piccardi et al. (1998). In our findings, the higher levels of $\mathrm{Zn}$ found in the outermost layer of blubber compared to the intermediary and innermost ones seem also to corroborate this important role of $\mathrm{Zn}$ for protection against UV damages.

Mercury is a non-essential element, not subjected to homeostasis, and it is one of the trace elements of most concern because of its high toxicity and its behaviour in the marine environment and biota. Thus, this element biomagnifies along the food webs and marine mammals present generally important Hg concentrations (Law et al., 1991; Law, 1996; Das et al., 2003). Bioaccumulation of $\mathrm{Hg}$ with age has been described for numerous tissues and various marine mammal species (e.g. Itano et al., 1984; André et al., 1991; Monaci et al., 1998; Caurant et al., 1994; Bustamante et al., 2004). More specifically, the significant $\mathrm{Hg}$ accumulation with age obtained in skin has been previously established in cetaceans as in the case of $\mathrm{Zn}$ (discussed above). However, and to the best of our knowledge, this is the first time that an increase of $\mathrm{Hg}$ concentrations with age in blubber is reported in cetaceans. In the four species we analysed, $\mathrm{Hg}$ concentrations were ranked in the following pattern: liver > kidney > skin > blubber, which is in agreement with the results of these previous studies on different cetacean species (i.e. Cardellicchio et al., 2000; Frodello et al., 2000; Carvalho et al., 2002; Roditi-Elasar et al., 2003; Hong et al., 2012). Significant differences in elemental concentrations among tissues suggest preferential organs for the deposition of each element according to its chemical affinity and the specific function of the tissue. Indeed, liver is known to be the storage organ of $\mathrm{Hg}$ for marine mammals (e.g. Wagemann et al., 1998; Aguilar et al., 1999), while the epidermis might be a significant route of elimination of that metal, especially in moulting species like beluga (Wagemann and Kozlowska, 2005). In addition, $\mathrm{Hg}$ is known to be mainly under its methylated form (i.e. methyl- $\mathrm{Hg}$ ) in marine organisms (e.g. > 95\% in fish) (Bloom, 1992; Mason et al., 1995); and that the biomagnification of $\mathrm{Hg}$ resembles that of hydrophobic organic pollutants rather than that of ionic metals, and it is generally thought to result from the lipid solubility of methyl-Hg (Monteiro et al., 1996). High lipid contents in the blubber of marine mammals would therefore lead to high methyl-Hg concentrations. However, if we consider $\mathrm{Hg}$ chemical 
properties, this element has a low octanol-water distribution coefficient (Kow) compared to other fat soluble compounds such as DDT or PCBs (Bienvenue et al., 1984; Veith et al., 1980). Unlike other hydrophobic compounds, methyl-Hg seems to have a strong affinity for the sulphydryl groups of certain proteins and resides in muscular proteins rather than in fat tissue in fish (Bloom, 1992). Thus, low methyl-Hg content in the blubber of marine mammals could be due to a preferential redistribution to muscular tissues, resulting in a low total $\mathrm{Hg}$ concentration in this fat tissue. Our result is in agreement with those of previous studies carried on marine mammals (Carvalho et al., 2002) and even on the digestive gland (i.e. fat tissue) of several species of cephalopods (Bustamante et al., 2006).

\subsection{Use of skin and blubber biopsies to estimate trace element concentrations in internal organs}

Most studies on contaminants in cetaceans are based on tissues sampled from stranded or bycaught animals. Using biopsies obtained from free-ranging specimens would allow improving this opportunistic sampling to a more regular and representative ones, and giving the opportunity to sample geographical areas where carcasses are usually not available or species more rarely subject to stranding or by-caught events. Moreover, in many cases, the cause of the death of stranded cetaceans is unknown, and sick or parasitic animals may have uptake and/or bioaccumulated some contaminants when normal physiological functions are altered (Aguilar et al., 1999). Similarly, contaminant body loads of diseased animals may likely be abnormal when tissues have begun to decompose (Thompson, 1990). For all these reasons, using skin or blubber tissues obtained from free-ranging cetaceans whenever possible may appear like a good complement for tissues from stranded and/or by-caught individuals, especially for the purpose of monitoring the contamination of wild and healthy populations. Nonetheless, very few toxicological indicators are available to assess the effects of trace element concentrations in skin or blubber, though a recent study has established baseline levels of trace elements in blood and skin of bottlenose dolphins with the perspective of a non-invasive monitoring (Bryan et al., 2007). However, the reference organs when investigating the effects of trace elements bioaccumulation in cetaceans commonly are kidneys and liver. Thus, damages, effects or abnormalities of $\mathrm{Hg}$ concentrations have been reported in those tissues of marine mammals (Wagemann and Muir, 1984; Dietz et al., 1996; Law, 1996; AMAP, 1998), suggesting a toxic threshold for hepatic Hg concentrations of 300 $\mu \mathrm{g} \cdot \mathrm{g}^{-1} \mathrm{dw}$ (Law, 1996; AMAP, 1998). The hepatic Hg concentrations obtained from this study 
and the previous ones ranged from 0.8 to $1173 \mu \mathrm{g} \cdot \mathrm{g}^{-1} \mathrm{dw}$ across all individuals, with only five individuals exhibiting concentrations within the suggested toxic threshold and ranged from 644 to $1173 \mu \mathrm{g} \cdot \mathrm{g}^{-1} \mathrm{dw}$.

Moreover, among all the analysed trace elements in this study, $\mathrm{Hg}$ is the only one showing correlations between all combinations of tissue-to-tissue concentrations, including either skin or blubber for each species and across all individuals. However, the smoothing lines based on the LOWESS algorithm and representing the fitted non-linear trend of the values (Fig. 5), shows that $\mathrm{Hg}$ correlation between blubber and kidney concentrations is much more hazardous above a limit value of $2 \mu \mathrm{g} \cdot \mathrm{g}^{-1} \mathrm{dw}$ in blubber, whereas correlation is still significant with liver concentrations. For skin concentrations, a limit value of $6 \mu \mathrm{g} \cdot \mathrm{g}^{-1} \mathrm{dw}$ seems to be relevant for relationship with kidney and slightly lower for liver. Very few tissue-to-tissue correlations were detected for the other elements. As example the positive relation obtained between $\mathrm{Cu}$ concentrations in blubber and those in kidney for common dolphins (Table 4). This particular relationship has also been detected for pooled Mediterranean individuals of bottlenose and striped dolphin (Roditi-Elasar et al., 2003).

The significant positive correlations in $\mathrm{Hg}$ concentrations between external and internal tissues suggest that cutaneous and sub-cutaneous $\mathrm{Hg}$ concentrations could be used to assess hepatic and renal $\mathrm{Hg}$ levels in the studied species. These results confirmed the positive correlations between skin and liver $\mathrm{Hg}$ concentrations established previously in cetacean species like Dall's porpoise (Yang et al., 2002), striped dolphin (Monaci et al., 1998) or bottlenose dolphin (Stavros et al., 2011). However, investigating correlations between liver and skin trace element concentrations in minke whales from the southern hemisphere by Kunito et al. (2002), reported positive correlations for $\mathrm{Mn}, \mathrm{Cu}$ and $\mathrm{Zn}$, but not for $\mathrm{Hg}$, with the concentrations following the order $\mathrm{Zn}>\mathrm{Cu}>\mathrm{Mn} / \mathrm{Hg}$, and with large interannual variations observed in the skin accumulation of one of the areas studied (i.e. Area $\mathrm{V} 103^{\circ} \mathrm{E}$ $\left.160^{\circ} \mathrm{W}\right)$. This temporal difference might be due to the considerable interannual changes in food mass and prey availability in this area, modifying element accumulation in the skin of southern minke whales. Thus, the different results obtained by Kunito et al. (2012) and the current study might be linked to the facts 1) that a baleen whale such minke whale feeds at a lower trophic levels (primarily on Antarctic krill) and consequently accumulates much less $\mathrm{Hg}$ in the liver than toothed whales, such small cetaceans, and 2) that baleen plate as a keratinous tissue is probably a more efficient way of elimination of $\mathrm{Hg}$ than skin. Indeed, $\mathrm{Hg}$ concentrations in baleen are significantly correlated with concentrations in liver and kidney for North Atlantic minke whales (Hobson et al., 2004). 
As we have discussed in the introduction, biopsy darting is a remote sampling strategy developed to collect small samples of skin and blubber tissues from free-ranging marine mammals, primarily for genetic studies of population or pollutant monitoring (e.g. Gauthier et al., 1997), but also for trophic ecology through stable isotope analysis for example (e.g. Hooker et al., 2001; Herman et al., 2005; Kizska et al., 2010; Witteveen et al., 2011). However, this technique allows usually collecting samples from the outer strata of blubber for whales, and doubts remain whether these small samples are representative of contamination of the entire blubber layer. Indeed, biopsies are mainly obtained from cetaceans by shooting a biopsy dart with a pole, rifle or crossbow, and the ability to attain suitable and intact samples including both skin and all blubber is linked to the angle of impact as well as the location on the body where the dart strikes (Noren and Mocklin, 2012).

Concerning organic lipophilic pollutants, some studies have shown for example that biopsies from the outer blubber layer could provide a good representation of the contamination by polychlorinated biphenyls (PCBs) and other organochlorines (OC) of the blubber in small cetaceans (Tanabe et al., 1981) and in balaenopterid whales (Gauthier et al., 1997). However, Aguilar and Borrell (1991) found higher concentrations of PCB and DDT in the outer region than in the inner one of the blubber mantle of fin whales (Balaenoptera physalus), resulting likely from the different lipid content and dynamics of fat storage within the different layers. In our study, the absence of interstrata differences in $\mathrm{Fe}, \mathrm{Hg}$, Mn and $\mathrm{Ni}$ concentrations seems to indicate that the outer blubber layer is a representative sample for cetacean blubber for those elements. Nevertheless, the outermost blubber layer, the subcutaneous one, exhibit significantly higher $\mathrm{Zn}$ concentrations than the two other layers, which could be the result of the important $\mathrm{Zn}$ skin burden as discussed previously. Moreover, though this difference was not significant for $\mathrm{Cu}$, nearly the same pattern than $\mathrm{Zn}$ could be observed for this element. It is interesting to notice, that for $\mathrm{Hg}$, no difference between the layers was found and therefore, facilitates the validation of biopsy sampling as a technique for monitoring hepatic and renal concentrations of $\mathrm{Hg}$. For evaluating blubber concentrations, this potential interlayer difference in levels for some trace elements should be considered, and the outermost layer or the first half outer centimetre of cetacean blubber tissue should be routinely used for contaminant investigation. 


\section{Conclusion}

Several trace elements were studied with internal (liver and kidney) and external tissues (skin and biopsies) of four species of small cetaceans form the NE Atlantic waters. Results showed that elemental concentrations varied among the four tissues, and were generally greater in liver than in kidney and in skin than in blubber. The significant tissue-to-tissue correlations for $\mathrm{Hg}$ concentrations found for each species and across all individuals, suggest that skin and blubber biopsies are suitable for investigating bioaccumulation of $\mathrm{Hg}$ in internal tissues such as kidneys and liver in the four cetacean species investigated, and can therefore be used as non-invasive monitoring tissues of free-ranging populations and to monitor geographic areas where carcasses are unusual. However, when possible, blubber will be chosen because of the more hazardous relationship between skin and liver concentrations above a threshold value (6 $\left.\mu \mathrm{g} \cdot \mathrm{g}^{-1} \mathrm{dw}\right)$. Contrarily, the absence of clear relationships between external and internal tissue levels for the other trace elements do not allow validating the use of skin and blubber biopsies to assess their burden in internal organs or the toxicological risks associated.

More generally, our results suggest that $\mathrm{Hg}$ measurements in skin and blubber biopsies of free-ranging individuals could contribute to provide valuable information on the status of $\mathrm{Hg}$ contamination, and even to inform on potential spatial variations. For the Atlantic coast, this encourages to extend the actual opportunistic sampling based on tissues collected on stranded individuals on the Northeast Atlantic coast to a more regular and representative one with inputs of tissue biopsies on wild specimens, in order to reinforce previous studies based on stranded and/or by-caught animals which already described the pertinence and usefulness of trace elements as chemical tracers for a better understanding of the geographical distribution or even structure of populations of cetacean species in this geographic area. 
Acknowledgements: We greatly acknowledge the stranding networks from France (Observatoire PELAGIS), Spain (CEMMA), and Portugal (SPVS) for providing us cetacean samples. We also thank A. F. Guerra and F. Read from the Instituto de Investigaciones Marinas (C.S.I.C) in Vigo, Spain, and W. Dabin from the Observatoire PELAGIS in La Rochelle, France, for the age determination of the individuals. We also wish to thank $\mathrm{C}$. Pignon-Mussaud from the Cellule Géomatique (UMR LIENSs) for providing the map of the study area and M. Kalombo from the Centre Commun d'Analyses (Fédération de Recherche en Environnement pour le Développement Durable FR 3097 CNRS-IFREMER-Université de La Rochelle) for running part of the trace element analyses. This work has been funded by the CPER 13 (Contrat de Plan Etat Région) through a post-doctoral grant to AA and PMF acknowledges support from the Portuguese Foundation for Science and Technology of the Government of Portugal (SFRH/BD/36766/2007). 


\section{References}

Aguilar, A., Borrell, A., 1991. Heterogeneous distribution of organochlorine contaminants in the blubber of baleen whales: implications for sampling procedures. Mar. Environ. Res. 31, $275-286$.

Aguilar, A., Borrell, A., Pastor, T., 1999. Biological factors affecting variability of persistent pollutant levels in cetaceans. J. Cetacean Res. Manag. (Special issue 1), 83-116.

AMAP. 1998. AMAP Assessment Report: Arctic Pollution Issues. Arctic Monitoring and Assessment Program (AMAP), pp. 859.

André, J.M., Boudou, A., Ribeyre, F., 1991. Mercury accumulation in Delphinidae. Wat. Air Soil Pollut. 56(1), 187-201

Bellante, A., Sprovieri, M., Buscaino, G., Salvagio Manta, D., Buffa, G., Di Stefano, V., Bonanno, A., Barra, M., Patti, B., Giacoma, C., Mazzola, S., 2011. Stranded cetaceans as indicators of mercury pollution in Mediterranean Sea. Ital. J. Zool. 1, 1-10.

Bienvenue, E., Boudou, A., Desmazes, J.P., Gavach, C., Georgescauld, D., Sandeaux, J., Seta, P., 1984. Transport of mercury compounds across biomolecular lipid membranes: effect of lipid composition, pH, chloride concentration. Chem-Biol. Interact. 48, 91-101.

Bloom, N.S., 1992. On the chemical form of mercury in edible fish and marine invertebrate tissue. Can. J. Fish. Aquat. Sci. 49, 1010-7.

Bowles, D., 1999. An overview of the concentrations and effects of metals in cetacean species. J. Cetacean Res. Manag. (Special issue 1), 125-148.

Bryan, G.W., 1984. Pollution due to heavy metals and their compounds, in: Kinne, O. (Ed.), Marine ecology, vol. 5, part 3. Chichester, Wiley-Interscience, pp. 1289-1431.

Bryan, C., Christopher, S., Balmer, B., Wells, R., 2007. Establishing baseline levels of trace elements in blood and skin of bottlenose dolphins in Sarasota Bay, Florida: implications for non-invasive monitoring. Sci. Total Environ. 388, 325-342.

Bustamante, P., Garrigue, C., Breau, L., Caurant, F., Dabin, W., Greaves, J., Dodemont, R., 2003. Trace elements in two odontocete species (Kogia breviceps and Globicephala macrorhynchus) stranded in New Caledonia (South Pacific). Environ. Pollut. 124, 263271.

Bustamante, P., Morales, C.F., Mikkelsen, B., Dam, M., Caurant, F., 2004. Trace element bioaccumulation in grey seals Halichoerus grypus from the Faroe Islands. Mar. Ecol. Progr. Ser. 267, 291-301. 
Bustamante, P., Lahaye, V., Durnez, C., Churlaud, C., Caurant, F., 2006. Total and organic $\mathrm{Hg}$ concentrations in cephalopods from the North Eastern Atlantic waters: Influence of geographical origin and feeding ecology. Sci. Tot. Environ. 368, 585-596.

Caurant, F., J.C. Amiard, C. Amiard-Triquet and P.G. Sauriau, 1994. Ecological and biological factors controlling the concentrations of trace elements ( $\mathrm{As}, \mathrm{Cd}, \mathrm{Cu}, \mathrm{Hg}, \mathrm{Se}, \mathrm{Zn}$ ) in delphinids Globicephala melas from the North Atlantic Ocean. Mar. Ecol. Prog. Ser. 103, 207-219.

Cardellicchio, N., Giandomenico, S., Ragone, P., Di Leo, A., 2000. Tissue distribution of metals in striped dolphins (Stenella coeruleoalba) from the Apulian coasts, Southern Italy. Mar. Environ. Res. 49, 55-66.

Carvalho, M.L., Pereira, R.A., Brito, J., 2002. Heavy metals in soft tissues of Tursiops truncatus and Delphinus delphis from West Atlantic Ocean by X-ray spectrometry. Sci. Total Environ. 292, 247-254.

Christopher, S.J., Pugh, R.S., Ellisor, M.B., Mackey, E.A., Spatz, R.O., Porter, B.J., Bealer, K.J., Kucklick, J.R., Rowles, T.K., Becker, P.R., 2007. Description and results of the NIST/NOAA 2005 interlaboratory comparison exercise for trace elements in marine mammals. Accred. Qual. Assur. 12, 175-187.

Das, K., Debacker, V., Pillet, S., Bouquegneau J.M., 2003. Heavy metals in marine mammals. In: Vos, J.V., Bossart, G.D., Fournier, M., O’Shea, T.J. (Eds.), Toxicology of Marine Mammals. Taylor and Francis Publishers, Washington D.C., pp. 135-167.

Dietz, R., Riget, F., Johansen, P., 1996. Lead, cadmium, mercury and selenium in Greenland marine animals. Sci. Total Environ. 186 (1-2), 67-93.

Emonet-Piccardi, N., Richard, M.J., Ravanat, J.L., Signorini, N., Cadet, J., Béani, J.C., 1998. Protective effects of antioxidants against UVA-induced DNA damage in human skin fibroblasts in culture. Free Radic. Res. 29, 307-313.

Fossi, M.C., Marsili, L., 1997. The use of non-destructive biomarkers in the study of marine mammals. Biomarkers 2, 205-216.

Fossi, M.C., Marsili, L., Lauriano, G., Fortuna, C., Canese, S., Ancora, S., Leonzio, C., Romeo, T., Merino, R., Abad, E., Jiménez, B., 2004. Assessment of toxicological status of a SW Mediterranean segment population of striped dolphin (Stenella coeruleoalba) using skin biopsy. Mar. Environ. Res. 58, 269-274.

Frodello, J.P., Romeo, M., Viale, D., 2000. Distribution of mercury in the organs and tissues of five toothed-whale species of the Mediterranean. Environ. Pollut. 108, 447-452. 
Fujise, Y., Honda, K., Tatsukawa, R., Mishima, S., 1988. Tissue distribution of heavy metals in Dall's porpoises in the Northwestern Pacific. Mar. Pollut. Bull. 19, 226-230.

Gauthier, J.M., Metcalfe, C.D., Sears, R., 1997. Validation of the blubber biopsy technique for monitoring of organochlorine contaminants in balaenopterid whales. Mar. Environ. Res. 43, 157-179.

Herman, D.P., Burrows, D.G., Wade, P.R., Durban, J.W., Matkin, C.O., LeDuc, R.G., BarrettLennard, L.G., Krahn, M.M., 2005. Feeding ecology of eastern North Pacific killer whales Orcinus orca from fatty acid, stable isotope, and organochlorine analyses of blubber biopsies. Mar. Ecol. Progr. Ser. 302, 275-291.

Hicks, B.D., St Aubin, D.J., Geraci, J.R., Brown, W.R., 1985. Epidermal growth in the bottlenose dolphin, Tursiops truncatus. J. Invest. Dermatol. 85, 60-63.

Hobson, K.A., Riget, F.F., Outridge, P.M., Dietz, R., Born, E.W., 2004. Baleen as a biomonitor of mercury content and dietary history of North Atlantic Minke Whales (Balaenopetra acutorostrata): combining elemental and stable isotope approaches. Sci. Total Environ. 331, 69-82.

Hohn, A.A., Lockyer, C., 1995. Protocol for obtaining age estimates from harbour porpoise teeth. Appendix 3, Report of the harbour porpoise age determination workshop. In: Bjørge, A., Donovan, G.P., (Eds) Biology of Phocoenids. Cambridge, IWC, pp. 478-493.

Honda, K., Tatsukawa, R., Fuhiyama, T., 1982. Distribution characteristics of heavy metals in the organs and tissues of striped dolphin, Stenella coeruleoalba. Agric. Biol. Chem. 46, 3011-3021.

Hong, Y.S., Hunter, S., Clayton, L.A., Rifkin, E., Bouwer, E.J., 2012. Assessment of mercury and selenium concentrations in captive bottlenose dolphins (Tursiops truncatus) diet fish, blood, and tissue. Sci. Total Environ. 414, 220-226.

Hooker, S.K., Iverson, S.J., Ostrom, P., Smith, S.C., 2001. Diet of northern bottlenose whales inferred from fatty-acid and stable-isotope analyses of biopsy samples. Can. J. Zool. 79, $1442-1454$.

Itano, K., Kawai, Si., Miyazaki, N., Tatsukawa, R., Fujiyama, T., 1984. Mercury and selenium levels in striped dolphins caught off the Pacific Coast of Japan. Agric. Biol. Chem. 48, 1109-1116.

Kiszka, J., Oremus, M., Richard, P., Poole, M., Ridoux, V., 2010. The use of stable isotope analyses from skin biopsy samples to assess trophic relationships of sympatric delphinids off Moorea (French Polynesia). J. Exp. Mar. Biol. Ecol. 395, 48-54. 
Krützen, M., Barré, L.M., Möller, L.M., Heithaus, M.R., Simms, C., Sherwin, W.B., 2002. A biopsy system for small cetaceans: Darting success and wound healing in Tursiops spp. Mar. Mamm. Sci. 18, 863-878.

Kuiken, T., Garcia-Hartmann, M., 1991. Proceedings of the first European Cetacean Society workshop on 'Cetacean pathology: dissection techniques and tissue sampling'. ECS Newslett. 17, 1-39.

Kunito, T., Watanabe, I., Yasunaga, G., Fujise, Y., Tanabe, S., 2002. Using trace elements in skin to discriminate the populations of minke whales in southern hemisphere. Mar. Environ. Res. 53, 175-197.

Lahaye, V., Bustamante, P., Spitz, J., Dabin, W., Das, K., Pierce, G.J., Caurant, F., 2005. Long-term dietary segregation of short-beaked common dolphins (Delphinus delphis) in the Bay of Biscay determined using cadmium as an ecological tracer. Mar. Ecol. Prog. Ser. $305,275-285$.

Lahaye, V., Bustamante, P., Dabin, W., Van Canneyt, O., Dhermain, F., Cesarini, C., Pierce, G.J., Caurant, F., 2006. New insights from age determination on toxic element accumulation in striped and bottlenose dolphins from Atlantic and Mediterranean waters. Mar. Pollut. Bull. 52, 1219-1230.

Lahaye, V., Bustamante, P., Dabin, W., Churlaud, C., Caurant, F., 2007a. Trace element levels in foetus-mother pairs of short-beaked common dolphins (Delphinus delphis) stranded along the French coasts. Environ. Int. 33, 1021-1028.

Lahaye, V., Bustamante, P., Law, R.J., Learmonth, J.A., Santos, M.B., Boon, J.P., Rogan, E., Dabin, W., Addink, M.J., López, A., Zuur, A.F., Pierce, G.J., Caurant, F., 2007b. Biological and ecological factors related to trace element levels in harbour porpoises (Phocoena phocoena) from European waters. Mar. Environ. Res. 64, 247-266.

Law, R.J., Fileman, C.F., Hopkins, A.D., Baker, J.R., Harwood, J., Jackson, D.B., Kennedy, S., Martin, A.R., Morris, R.J., 1991. Concentrations of trace metals in the livers of marine mammals (seals, porpoises and dolphins) from waters around British Isles. Mar. Pollut. Bull. 22, 183-191.

Law, R.J., Jones, B.R., Baker, J.R., Kennedy, S., Milne, R., Morris, R.J., 1992. Trace metals in the livers of marine mammals from the Welsh coast and the Irish Sea. Mar. Pollut. Bull. 24, 296-304.

Law, R.J., 1996. Metals in marine mammals, in: Beyer, W.N., Heinz, G.H., RedmonNorwood, A.W. (Eds.), Environmental Contaminants in Wildlife - Interpreting Tissue Concentrations. SETAC, CRC Press, Inc., pp. 357-376. 
Lockyer, C.,1993. A report on patterns of deposition of dentine and cement in teeth of pilot whales, genus Globicephala. Rep. Int. Whal. Comun. Spec. Issue. 14, 138-161.

Marcovecchio, J.E., Moreno, V.J., Bastida, R.O., Gerpe, M.S., Rodriguez, D.H., 1990. Tissue distribution of heavy metals in small cetaceans from the Southwestern Atlantic Ocean. Mar. Pollut. Bull. 21, 299-304.

Mason, R.P., Reinfelder, J.R., Morel, F.M.M., 1995. Bioaccumulation of mercury and methylmercury. Water Air Soil Pollut. 80, 915-921.

Méndez-Fernandez,P., Pierce, G.J., Bustamante, P., Chouvelon, T., Ferreira, M., González, A., López, A., Read, F., Santos, M.B., Spitz, J., Vingada, J.V., Caurant, F., in press. Ecological niche segregation among five toothed whale species off the NW Iberian Peninsula using ecological tracers as multi-approach. Mar Biol

Monaci, F., Borrel, A., Leonzio, C., Marsili, L., Calzada, N., 1998. Trace elements in striped dolphins (Stenella coeruleoalba) from the western Mediterranean. Environ. Pollut. 99, 6168.

Monteiro, L.R., Costa, V., Furness, R.W., Santos, R.S., 1996. Mercury concentrations in prey fish indicate enhanced bioaccumulation in mesopelagic environments. Mar. Ecol. Prog. Ser. $141,21-5$.

Muir, D.C.G., Wagemann, R., Grift, N.P., Norstrom, R.J., Simon, M., Lien, J., 1988. Organochlorine chemical and heavy metal contaminants in white-beaked dolphins (Lagenorhyncus albirostris) and pilot whales (Globicephala melaena) from the coast of Newfoundland. Arch. Environ. Contam. Toxicol. 17, 613-629.

Noren, D.P., Mocklin, J.A., 2012. Review of cetacean biopsy techniques: Factors contributing to successful sample collection and physiological and behavioral impacts. Mar. Mamm. Sci. 28, 154-199.

O'Shea T., 1999. Environmental Conyaminants and Marine Mammals. In: Reynolds, J.E.I., Rommel, S.A., (Eds.), Biology of Marine Mammals, Washington \& London: Smithsonian Institution Press, pp. 485-563.

Perrin, W.F, Myrick, A.C., 1980. Age determination of toothed whales and sirenians. Report of the International Whaling Commission, Special Issue 3, Cambridge, UK.

R Development Core Team, 2010. R: a language and environment for statistical computing. $\mathrm{R}$ Foundation for Statistical Computing, Vienna, www.R-project.org.

Roditi-Elasar, M., Kerem, D., Hornung, H., Kress, N., Shoham-Frider, E., Goffman, O., Spanier, E., 2003. Heavy metal levels in bottlenose and striped dolphins off the Mediterranean coast of Israel. Mar. Pollut. Bull. 46, 503-512. 
Rogan, E., Murphy, S., Learmonth, J.A., González, A., Dabin, W., 2004. Age determination in small cetaceans from the NE Atlantic. In: Pierce, G.J., Santos, M.B., Learmonth, J.A., Smeenk, C., (Eds.), Bioaccumulation of persistent organic pollutants in small cetaceans in European waters: transport pathways and impact on reproduction, Appendix 4. Final Report to the European Commission's Directorate General for Research on Project EVK32000-00027, Aberdeen, pp. 34.

Stavros, H.C.W., Bossart, G., Hulsey, T., Fair, P.A., 2007. Trace element concentrations in skin of free-ranging bottlenose dolphins (Tursiops truncatus) from the southeast Atlantic coast. Sci. Total Environ. 388, 300-315.

Stavros, H.C.W., Stolen, M., Durden, W.N., McFee, W., Bossart, G.D., Fair, P.A., 2011. Correlation and toxicological inference of trace elements in tissues from stranded and freeranging bottlenose dolphins (Tursiops truncatus). Chemosphere 82, 1649-1661.

Thompson, D.R., 1990. Metals levels in marine vertebrates, In: Furness, R.W., Rainbow, P.S. (Eds.), Heavy metals in the marine environment. CRC Press, Boca Raton, pp. 143-182.

Veith, G.D., Macek, K.J., Petrocelli, S.R., Carrol, J., 1980 An evaluation of using coefficients and water solubility to estimate BCF for organic chemicals in fish. In: Eaton, J.G., Parrish, P.R., Hendricks, A.C., (Eds.), Aquatic toxicology, ASTM, Philadelphia, PA, pp. 117-119.

Wagemann, R., Muir, D.C.G., 1984. Concentrations of heavy metals and organochlorines in marine mammals of northern waters: overview and evaluation. Can. Tech. Rep. Fish. Aquat. Sci. 1279.

Wagemann, R., Innes, S., Richard, P.R., 1996. Overview and regional and temporal differences of heavy metals in arctic whales and ringed seals in the Canadian Arctic. Sci. Total Environ. 186, 41-66.

Wagemann, R., Trebacz, E., Boila, G., Lockhart, W.L., 1998. Methylmercury and total mercury in tissues of arctic marine mammals. Sci. Total Environ. 218, 19-31.

Wagemann, R., Kozlowska, H., 2005. Mercury distribution in the skin of beluga (Delphinapterus leucas) and narwhal (Monodon monoceros) from the Canadian Arctic and mercury burdens and excretion by moulting. Sci. Total Environ. 351-352, 333-343.

Watanabe, I., Ichihashi, H., Tanabe, S., Amano, M., Miyazaki, N., Petrov, E.A., Tatsukawa, R., 1996. Trace element accumulation in Baikal seal (Phoca sibirica) from the Lake Baikal. Environ. Pollut. 94, 169-179.

Witteveen, B.H., Straley, J.M., Chenoweth, E., Baker, C.S., Barlow, J., Matkin, C.O., Gabriele, C.M., Neilson, J., Steel, D., Ziegesar, O.V., Andrews, A.G., Hirons, A., 2011. Using movements, genetics and trophic ecology to differentiate inshore from offshore 
aggregations of humpback whales in the Gulf of Alaska. Endang. Species Res. 14, 217225.

Yamamoto, Y., Honda, K., Hidaka, H., Tatsukawa, R., 1987. Tissue distribution of heavy metals in Weddell seals (Leptonychotes weddellii). Mar. Pollut. Bull. 18, 164-169.

Yang, J.T., Kunito, S., Tanabe, S., Amano, M., Miyazaki, N., 2002. Trace elements in skin of Dall's porpoise (Phocoenoides dalli) from the northern waters of Japan: an evaluation for utilization as non-lethal tracers. Mar. Pollut. Bull. 45, 230-236. 


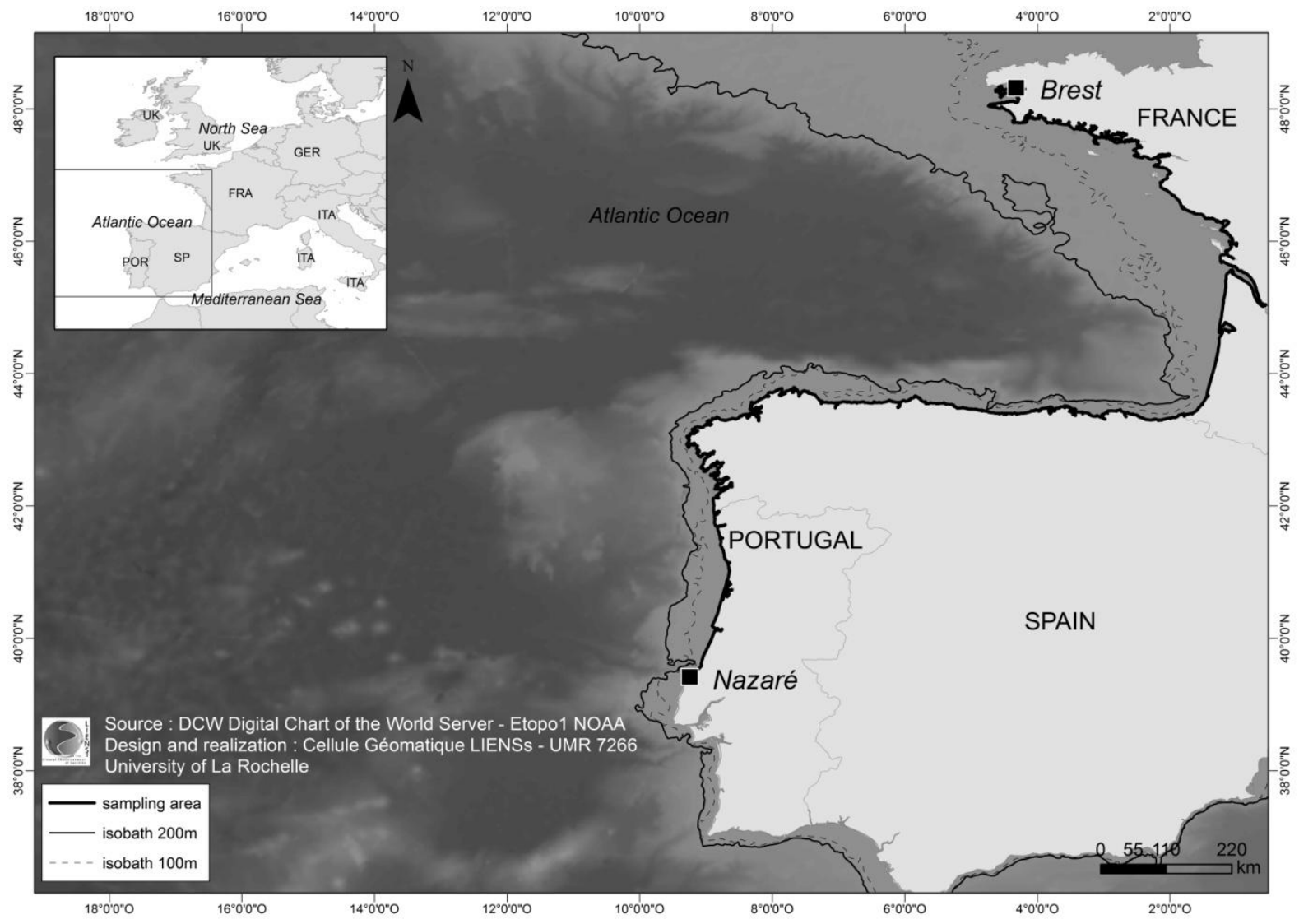

Fig. 1. Map showing the geographical area of tissues sampling. Black line contouring the coast represents the extension of the sampling area (from Nazare in Portugal to Brest in France). 

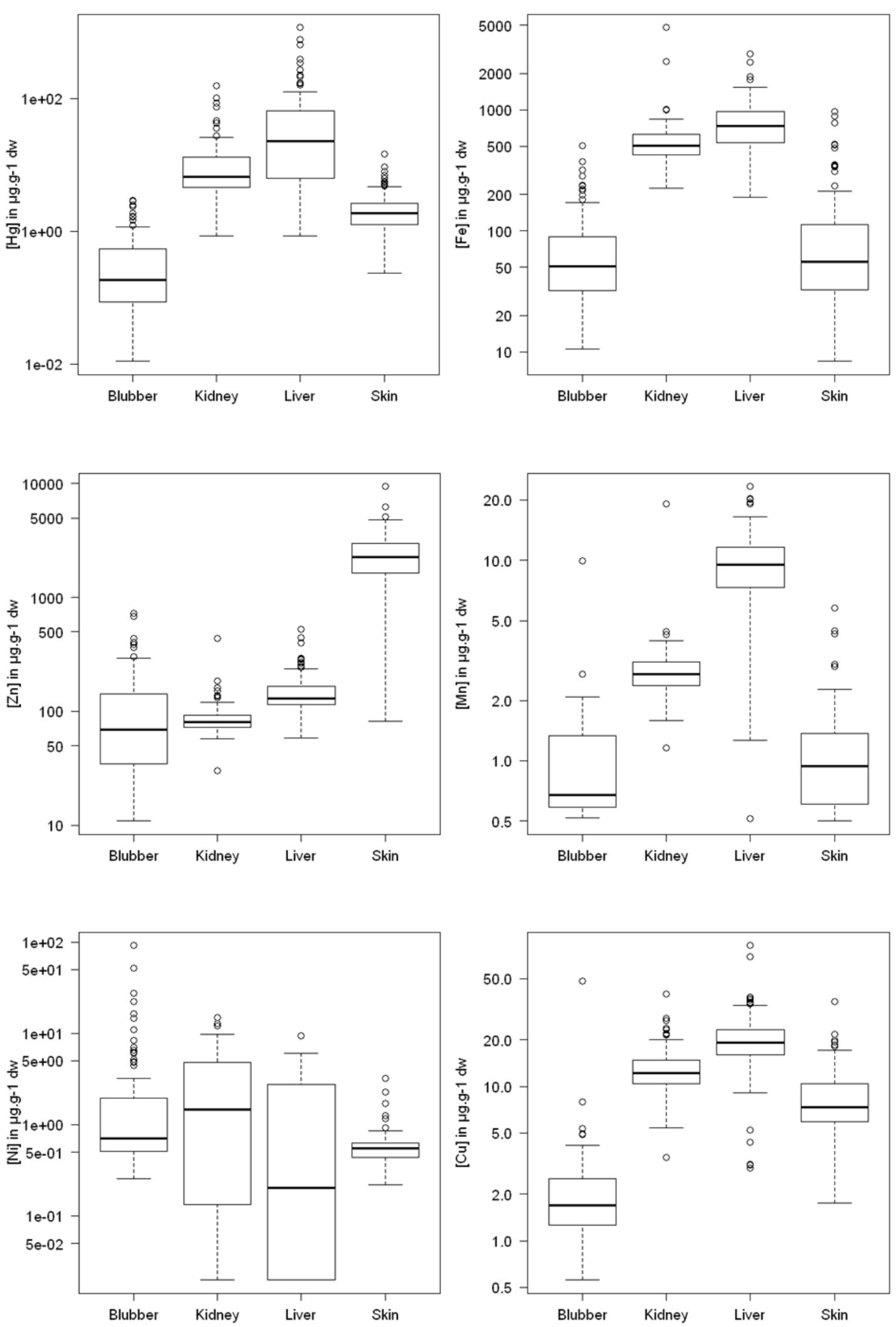

Fig. 2. Comparisons of trace element concentrations ( $\mu \mathrm{g} \mathrm{g}^{-1} \mathrm{dw}$, log-transformed) among the four tissues, i.e. blubber, kidney, liver and skin, for all individuals $(n=131)$ of the four species. The upper and lower hinges represent the quartiles, the vertical lines the maximum and minimum data values and the bold line represents the median value while the points are outliers. The y axes are logarithmic scales. Kidney and liver concentrations are from Lahaye et al. (2005, 2006, 2007a, 2007b) and Méndez-Fernandez et al. (in press). 

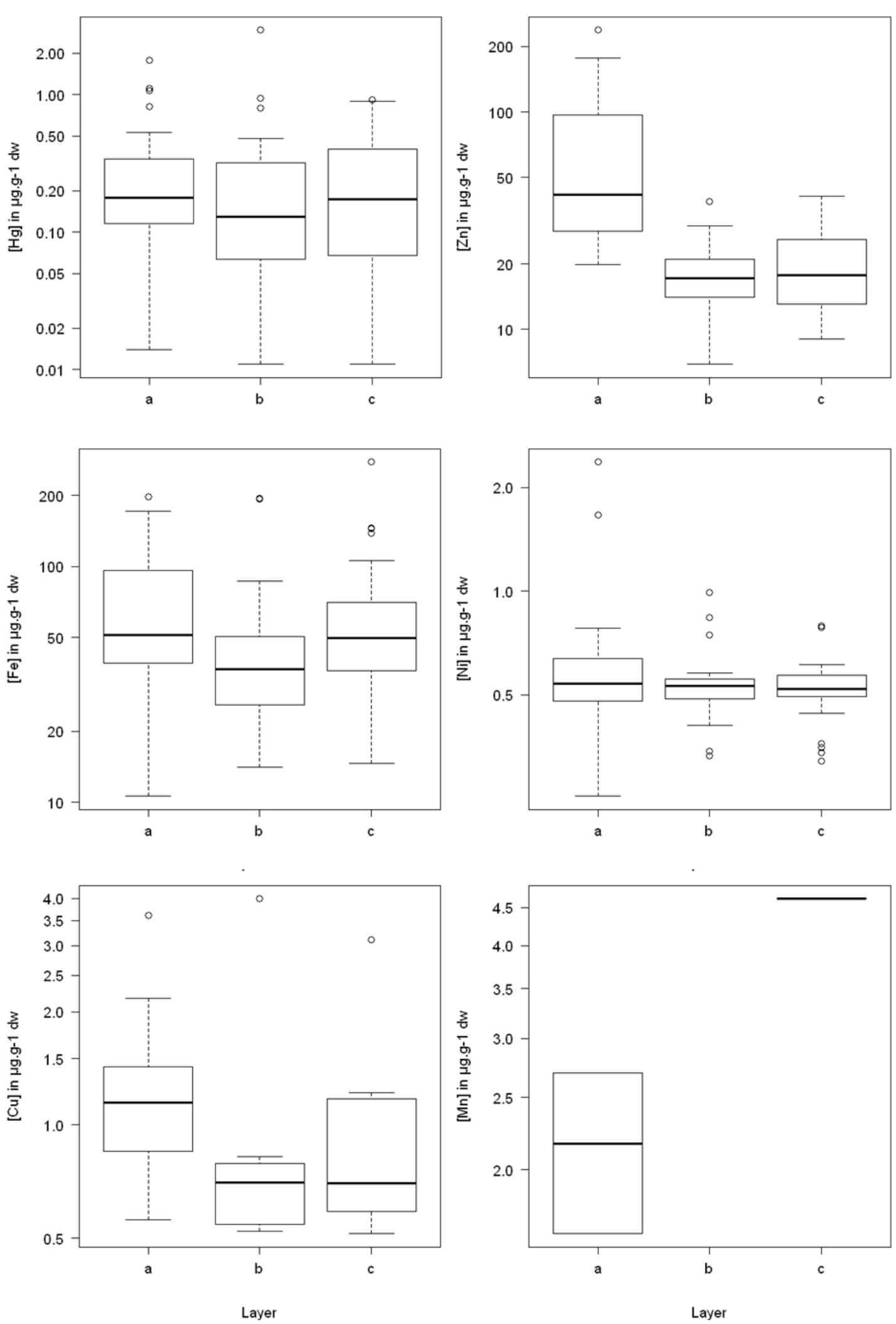

Fig. 3. Comparisons of trace element concentrations in blubber ( $\mu \mathrm{g} \cdot \mathrm{g}^{-1} \mathrm{dw}$, log-transformed) among the three layers, i.e. "a" being the outermost, "b" the intermediary and "c" the innermost one, for all 30 selected individuals. The upper and lower hinges represent the quartiles, the vertical lines the maximum and minimum data values and the bold line represents the median value while the points are outliers. The y axes are logarithmic scales. 

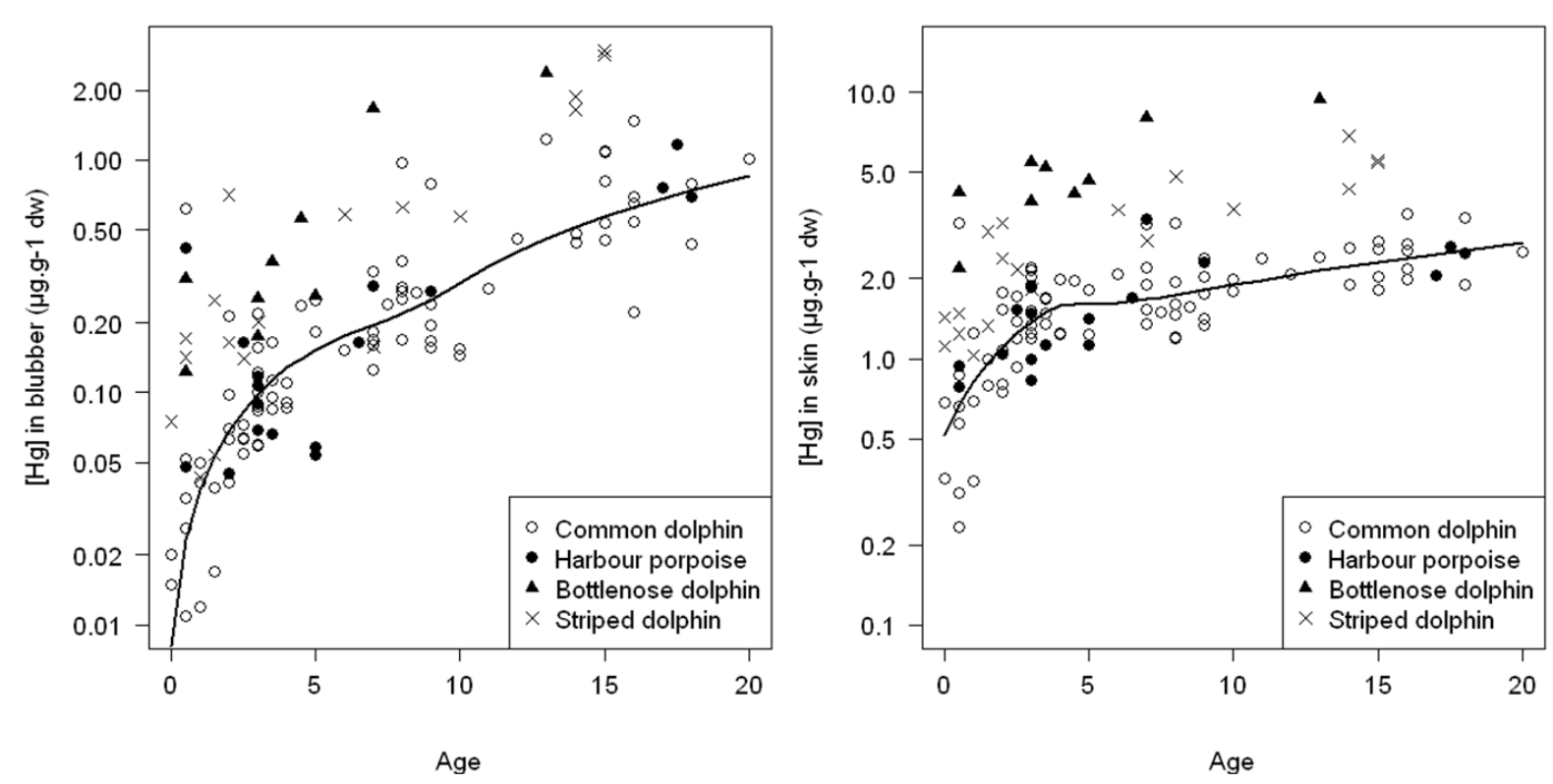

Fig. 4. Bioaccumulation of log-transformed $\mathrm{Hg}$ concentrations with age in blubber (on the left) and skin (on the right) of common dolphin Delphinus delphis, harbour porpoise Phocoena phocoena, bottlenose dolphin Tursiops truncatus and striped dolphin Stenella coeruleoalba. The smoothing line (robust, locally weighted scatter plot smoothing system based on the LOWESS algorithm) represents the fitted non-linear trend of the common dolphin values. The y axes are logarithmic scales. 

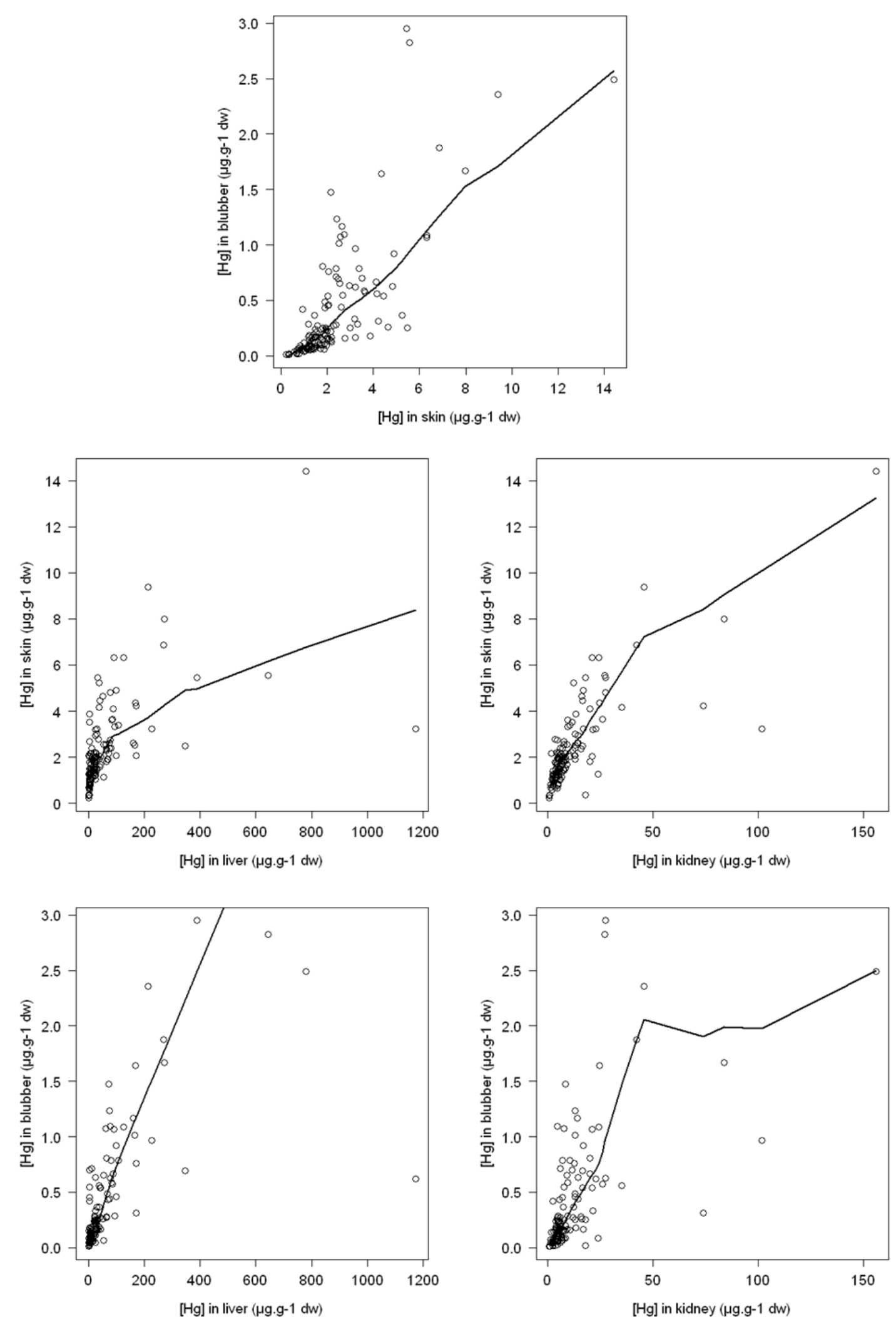

Fig. 5. Tissue-to-tissue correlations for $\mathrm{Hg}$ concentrations $\left(\mu \mathrm{g} \cdot \mathrm{g}^{-1} \mathrm{dw}\right.$ ) across all individuals (n $=131$ ) of the four species. The smoothing lines (robust, locally weighted scatter plot smoothing system based on the LOWESS algorithm) represent the fitted non-linear trend of the values. The y axes are logarithmic scales. 
Table 1. Characteristics of the cetacean specimens investigated, i.e. number, age (mean \pm SD) and sex ratio (number of females $(\mathrm{F}) /$ number of males $(\mathrm{M})$ ).

\begin{tabular}{lccc}
\hline \multicolumn{1}{c}{ Species } & $\mathrm{n}$ & $\begin{array}{c}\text { Age } \\
(\text { mean } \pm \mathrm{SD})\end{array}$ & $\begin{array}{c}\text { Sex } \\
(\mathrm{n}(\mathrm{F}) / \mathrm{n}(\mathrm{M}))\end{array}$ \\
\hline $\begin{array}{c}\text { Common dolphin } \\
\text { Delphinus delphis }\end{array}$ & 79 & $6.8 \pm 5.4$ & $30 / 47(2 \mathrm{nd})$ \\
$\begin{array}{c}\text { Harbour porpoise } \\
\quad \text { Phocoena phocoena }\end{array}$ & 17 & $6.2 \pm 5.8$ & $8 / 9$ \\
$\begin{array}{c}\text { Striped dolphin } \\
\quad \text { Stenella coeruleoalba } \\
\text { Bottlenose dolphin } \\
\text { Tursiops truncatus }\end{array}$ & 19 & $5.4 \pm 5.6$ & $9 / 10$ \\
\hline nd: not determined & 16 & $4.4 \pm 3.8(7 \mathrm{nd})$ & $9 / 7$ \\
\hline
\end{tabular}


Table 2. Trace element concentrations (mean $\pm \mathrm{SD}$ and range, in $\mu \mathrm{g} \cdot \mathrm{g}^{-1} \mathrm{dw}$ ) and number of samples with detectable concentration $(n)$ in blubber and skin of the four species studied. $\mathrm{N}=$ number of samples available per species.

\begin{tabular}{|c|c|c|c|c|c|c|c|c|}
\hline \multirow{3}{*}{$\begin{array}{l}\text { Species } \\
\mathrm{N} \\
\text { Element/Tissue }\end{array}$} & \multicolumn{2}{|c|}{$\begin{array}{l}\text { Common dolphin } \\
\text { Delphinus delphis }\end{array}$} & \multicolumn{2}{|c|}{$\begin{array}{c}\text { Harbour porpoise } \\
\text { Phocoena phocoena }\end{array}$} & \multicolumn{2}{|c|}{$\begin{array}{c}\text { Striped dolphin } \\
\text { Stenella coeruleoalba }\end{array}$} & \multicolumn{2}{|c|}{$\begin{array}{l}\text { Bottlenose dolphin } \\
\text { Tursiops truncatus }\end{array}$} \\
\hline & \multicolumn{2}{|c|}{79} & \multicolumn{2}{|c|}{17} & \multicolumn{2}{|c|}{19} & \multicolumn{2}{|c|}{16} \\
\hline & Blubber & Skin & Blubber & Skin & Blubber & Skin & Blubber & Skin \\
\hline \multirow[t]{3}{*}{$\mathrm{Hg}$} & $0.3 \pm 0.3$ & $1.7 \pm 0.7$ & $0.3 \pm 0.3$ & $1.6 \pm 0.7$ & $0.7 \pm 0.9$ & $3.0 \pm 1.7$ & $0.8 \pm 0.7$ & $5.7 \pm 2.9$ \\
\hline & $0.01-1.5$ & $0.2-3.5$ & $0.05-1.2$ & $0.8-3.3$ & $0.04-2.9$ & $1.03-6.8$ & $0.1-2.5$ & $2.2-14.4$ \\
\hline & $n=79$ & $n=79$ & $n=17$ & $n=17$ & $n=19$ & $n=19$ & $n=16$ & $n=16$ \\
\hline \multirow[t]{3}{*}{$\mathrm{Fe}$} & $64.9 \pm 48.2$ & $86.5 \pm 113$ & $51.2 \pm 29.9$ & $172 \pm 294$ & $54.1 \pm 37.7$ & $60.7 \pm 59.2$ & $176 \pm 138$ & $206 \pm 173$ \\
\hline & $12.8-234$ & $8.4-777$ & $14.8-119.1$ & $12.1-972$ & $10.6-145.8$ & $8.4-213$ & $25.8-502$ & $22-514$ \\
\hline & $n=79$ & $n=79$ & $n=17$ & $n=17$ & $n=19$ & $n=19$ & $n=16$ & $n=16$ \\
\hline \multirow[t]{3}{*}{$\mathrm{Cu}$} & $2.4 \pm 5.4$ & $9.0 \pm 4.8$ & $1.8 \pm 0.9$ & $6.8 \pm 3.7$ & $2.4 \pm 1.1$ & $7.8 \pm 4.2$ & $3.1 \pm 1.9$ & $8.5 \pm 2.8$ \\
\hline & $0.6-47.9$ & $3.3-35.2$ & $0.6-3.8$ & $1.8-15$ & $0.6-5.3$ & $2.4-18.5$ & $0.6-7.9$ & $6.2-18.1$ \\
\hline & $n=74$ & $n=79$ & $n=17$ & $n=17$ & $n=18$ & $n=19$ & $n=16$ & $n=16$ \\
\hline \multirow[t]{3}{*}{$\mathrm{Ni}$} & $1.8 \pm 3.6$ & $0.5 \pm 0.1$ & $1.9 \pm 1.9$ & $0.8 \pm 0.7$ & $10.9 \pm 24.4$ & $1 \pm 0.9$ & $6.01 \pm 13$ & $0.6 \pm 0.3$ \\
\hline & $0.30-22.1$ & $0.2-0.7$ & $0.3-6.5$ & $0.4-2.3$ & $0.3-91.5$ & $0.3-3.2$ & $0.3-51.3$ & $0.2-0.9$ \\
\hline & $n=58$ & $n=54$ & $n=12$ & $n=8$ & $n=14$ & $n=10$ & $n=15$ & $n=5$ \\
\hline \multirow[t]{3}{*}{$\mathrm{Zn}$} & $85.5 \pm 79.4$ & $2672 \pm 1272$ & $87.6 \pm 72.9$ & $2330 \pm 1273$ & $142 \pm 151$ & $2104 \pm 1151$ & $210 \pm 186$ & $2213 \pm 842$ \\
\hline & $16.5-407$ & $1189-9429$ & $10.9-279$ & $82.4-5139$ & $29.7-681$ & $1009-4379$ & $20.1-726$ & $1345-4808$ \\
\hline & $n=79$ & $n=79$ & $n=17$ & $n=17$ & $n=19$ & $n=19$ & $n=16$ & $n=16$ \\
\hline \multirow[t]{2}{*}{$\mathrm{Mn}$} & $0.7 \pm 0.5$ & $1.01 \pm 0.8$ & $0.8 \pm 0.4$ & $1.2 \pm 0.6$ & $1.2 \pm 0.7$ & $1 \pm 0.5$ & $2.2 \pm 3.2$ & $1.9 \pm 1.6$ \\
\hline & $\begin{array}{c}0.5-1.6 \\
n=5\end{array}$ & $\begin{array}{c}0.5-4.4 \\
n=23\end{array}$ & $\begin{array}{c}0.6-1.3 \\
n=3\end{array}$ & $\begin{array}{l}0.6-3 \\
n=15\end{array}$ & $\begin{array}{c}0.6-2.1 \\
n=5\end{array}$ & $\begin{array}{c}0.6-2.3 \\
n=12\end{array}$ & $\begin{array}{c}0.6-10 \\
n=8\end{array}$ & $\begin{array}{c}0.5-5.8 \\
n=8\end{array}$ \\
\hline
\end{tabular}


Table 3. Trace element concentrations (mean \pm SD and range, in $\mu \mathrm{g} \cdot \mathrm{g}^{-1} \mathrm{dw}$ ) and number of samples with detectable concentration $(n)$ in liver and kidney of the four species studied. N = number of samples available per species. Original data were published in Lahaye et al. (2005, 2006, 2007a, 2007b) and Méndez-Fernandez et al. (in press).

\begin{tabular}{|c|c|c|c|c|c|c|c|c|}
\hline \multirow{3}{*}{$\begin{array}{l}\text { Species } \\
\mathrm{N} \\
\text { Element/Tissue }\end{array}$} & \multicolumn{2}{|c|}{$\begin{array}{l}\text { Common dolphin } \\
\text { Delphinus delphis }\end{array}$} & \multirow{2}{*}{\multicolumn{2}{|c|}{$\begin{array}{c}\text { Harbour porpoise } \\
\text { Phocoena phocoena } \\
17\end{array}$}} & \multirow{2}{*}{\multicolumn{2}{|c|}{$\begin{array}{c}\text { Striped dolphin } \\
\text { Stenella coeruleoalba } \\
19\end{array}$}} & \multirow{2}{*}{\multicolumn{2}{|c|}{$\begin{array}{l}\text { Bottlenose dolphin } \\
\text { Tursiops truncatus } \\
16\end{array}$}} \\
\hline & \multicolumn{2}{|c|}{79} & & & & & & \\
\hline & Liver & Kidney & Liver & Kidney & Liver & Kidney & Liver & Kidney \\
\hline \multirow[t]{3}{*}{$\mathrm{Hg}$} & $43.5 \pm 134$ & $8.3 \pm 11.8$ & $60.4 \pm 90.3$ & $7.8 \pm 3.9$ & $99.5 \pm 167$ & $13.7 \pm 12$ & $129 \pm 189$ & $35.9 \pm 38.9$ \\
\hline & $0.8-1173$ & $0.8-102$ & $4.2-345$ & $2.7-16.6$ & $3.32-644$ & $1.7-42.3$ & $3.4-779$ & $4.9-156$ \\
\hline & $n=79$ & $n=79$ & $n=17$ & $n=17$ & $n=19$ & $n=19$ & $n=16$ & $n=16$ \\
\hline \multirow[t]{3}{*}{$\mathrm{Fe}$} & $704.2 \pm 267$ & $570 \pm 551$ & $1237 \pm 508$ & $639 \pm 152$ & $1162 \pm 590$ & $597 \pm 219$ & $822 \pm 421$ & $509 \pm 122$ \\
\hline & $190-1779$ & $225-4782$ & $619-2476$ & $458-990$ & $510-2906$ & $273-1006$ & $432-1407$ & $377-703$ \\
\hline & $n=79$ & $n=78$ & $n=10$ & $n=11$ & $n=15$ & $n=14$ & $n=6$ & $n=6$ \\
\hline \multirow[t]{3}{*}{$\mathrm{Cu}$} & $18.06 \pm 5.6$ & $12 \pm 2.5$ & $31.2 \pm 19$ & $14.3 \pm 4.6$ & $25 \pm 5.7$ & $15 \pm 6.2$ & $17.4 \pm 7.6$ & $15.1 \pm 7.8$ \\
\hline & $2.3-34.7$ & $5.4-20.04$ & $11.9-81.7$ & $9.1-26.8$ & $16.05-37.2$ & $3.5-27.4$ & $5.2-38$ & $7.2-39$ \\
\hline & $n=79$ & $n=78$ & $n=16$ & $n=17$ & $n=19$ & $n=18$ & $n=16$ & $n=16$ \\
\hline \multirow[t]{3}{*}{$\mathrm{Ni}$} & $2 \pm 0.06$ & $3.6 \pm 3.5$ & $0.03 \pm 0.03$ & $0.65 \pm 1.7$ & $0.3 \pm 0.8$ & $0.8 \pm 1.7$ & $0.5 \pm 1.04$ & $0.7 \pm 0.7$ \\
\hline & $0.02-9.5$ & $0.02-15$ & $0.02-0.09$ & $0.02-5.9$ & $0.02-3.2$ & $0.02-5.4$ & $0.02-2.6$ & $0.1-1.8$ \\
\hline & $n=79$ & $n=78$ & $n=10$ & $n=11$ & $n=15$ & $n=14$ & $n=6$ & $n=6$ \\
\hline \multirow[t]{3}{*}{$\mathrm{Zn}$} & $144 \pm 53.6$ & $84.2-43.3$ & $129 \pm 55$ & $88.4 \pm 13.3$ & $180 \pm 77.5$ & $108.1 \pm 34.3$ & $171 \pm 108$ & $83.6 \pm 19.6$ \\
\hline & $58.1-398$ & $30.07-436$ & $75.6-287$ & $68.7-121.1$ & $96.4-442$ & $66.5-184$ & $90.2-530$ & $57.5-133$ \\
\hline & $n=79$ & $n=78$ & $n=16$ & $n=17$ & $n=19$ & $n=18$ & $n=16$ & $n=16$ \\
\hline \multirow[t]{3}{*}{$\mathrm{Mn}$} & $9.2 \pm 3.6$ & $3 \pm 1.9$ & $8.1 \pm 7.3$ & $2.8 \pm 0.4$ & $9.1 \pm 6$ & $2.6 \pm 0.7$ & $3.01 \pm 4.1$ & $2.5 \pm 0.5$ \\
\hline & $0.5-23.3$ & $1.2-19.1$ & $0.3-20.4$ & $2.2-3.6$ & $0.3-20.1$ & $1.7-4.3$ & $0.2-11.2$ & $1.8-3.06$ \\
\hline & $n=79$ & $n=78$ & $n=10$ & $n=11$ & $n=15$ & $n=14$ & $n=6$ & $n=6$ \\
\hline
\end{tabular}


Table 4. Pearson's correlation coefficients of the significantly correlated variables for each species and across all individuals.

\begin{tabular}{|c|c|c|c|c|c|}
\hline & $\begin{array}{l}\text { Common dolphin } \\
\text { Delphinus delphis }\end{array}$ & $\begin{array}{c}\text { Harbour porpoise } \\
\text { Phocoena phocoena }\end{array}$ & $\begin{array}{c}\text { Striped dolphin } \\
\text { Stenella coeruleoalba }\end{array}$ & $\begin{array}{l}\text { Bottlenose dolphin } \\
\text { Tursiops truncatus }\end{array}$ & All species \\
\hline \multicolumn{6}{|l|}{$\overline{\mathbf{C u}}$} \\
\hline Blubber/kidney & $0.63 *$ & & & & $0.21 *$ \\
\hline Blubber/liver & & & & & $0.57 *$ \\
\hline Blubber/skin & & $0.59 *$ & & & \\
\hline \multicolumn{6}{|l|}{$\mathrm{Ni}$} \\
\hline Blubber/skin & & & & & $0.29 *$ \\
\hline Skin/kidney & & & & & $-0.26 *$ \\
\hline \multicolumn{6}{|l|}{ Mn } \\
\hline Skin/liver & & & & & $-0.30 *$ \\
\hline \multicolumn{6}{|l|}{$\mathrm{Fe}$} \\
\hline Blubber/skin & $0.35 * *$ & & & & $-0.37 * * *$ \\
\hline \multicolumn{6}{|l|}{$\mathbf{Z n}$} \\
\hline Blubber/kidney & & & & & $0.21 *$ \\
\hline Blubber/liver & $0.30 * *$ & & & & $0.25^{* *}$ \\
\hline Skin/liver & & & & & $-0.50 *$ \\
\hline \multicolumn{6}{|l|}{$\mathrm{Hg}$} \\
\hline Blubber/kidney & $0.68 * * *$ & $0.63 * *$ & $0.80 * * *$ & $0.70 * *$ & $0.74 * * *$ \\
\hline Blubber/liver & $0.78 * * *$ & $0.65 * *$ & $0.90 * * *$ & $0.84 * * *$ & $0.81 * * *$ \\
\hline Blubber/skin & $0.85 * * *$ & $0.67 * *$ & $0.90 * * *$ & $0.80 * * *$ & $0.84 * * *$ \\
\hline Skin/liver & $0.70 * * *$ & $0.76 * * *$ & $0.94 * * *$ & $0.81 * * *$ & $0.75 * * *$ \\
\hline Skin/kidney & $0.68 * * *$ & $0.79 * * *$ & $0.86 * * *$ & $0.78 * * *$ & $0.80 * * *$ \\
\hline
\end{tabular}

$* p<0.05, * * p<0.01, * * * p<0.001$ 